\section{Injury Analysis of Iran's Mining Workplaces}

Rudarsko-geološko-naftni zbornik

(The Mining-Geology-Petroleum Engineering Bulletin) UDC: 622.8

DOI: 10.17794/rgn.2021.1.2

Review scientific paper

\author{
Mohammad Javad Rahimdel \\ Department of Mining Engineering, Faculty of Engineering, University of Birjand, Birjand 9717434765, Iran
}

\begin{abstract}
Mining is a high-risk industry that exposes operators and workers to a high level of occupational health and safety hazards caused by vehicle accidents, blasting, or collapse. This paper aims to analyse the serious and fatal accidents in Iran's mines over a six-year period, from 2012 to 2017. The data sources were the statistical results of the occupational accidents reported by the National Statistical Centre of Iran and the importance measure of incidents defined by the questionnaires received from the mine safety and health experts. This research presents a model for the prioritization of the mining workplace based on the weighted injury risk of the occupational incidents in the mining industry. The results of this work show that the coal mines of Iran have the highest work-related incidence rate which requires special safety attention. Moreover, the total temporary disability risk is currently at the lowest level in all mining activities, while the fatality risk has significantly increased in the coal mines in recent years. The results obtained from this study are helpful to detect the dangerous mining workplaces and to protect workers from workplace hazards by considering the safety guidelines.
\end{abstract}

\title{
Keywords:
}

Mining workplace; Iran's mines; serious injuries; risk assessment

\section{Introduction}

Regarding the National Statistical Centre of Iran in 2019, there were more than five thousand active mines in Iran that employed more than nine thousand workers (NSCI 2019). Operating a mine is a hazardous activity and exposes workers and operators to numerous accidents that threaten their health and safety. Undesirable consequences of incidents such as partial disability (PD), total temporary disability (TTD), and total permanent disability (TPD), or even fatality (FY) cannot be eliminated, and therefore, studying and analyzing the frequency and magnitude of incidents using quantitative or qualitative approaches is essential. It is noted that PD is a type of disability in which the workers are working in a lesser capacity due to their injury or injuries. In TTD cases, the worker is entirely unable to work for a period of time. TPD is a type of disability in which a worker cannot work any longer because of injuries.

Nowadays, many researchers have studied the incidents and accordingly the health and safety risk during various stages of mining. A short list of these studies is given in Table 1.

As there are few reports studying the occupational injuries of mining accidents, the rest of this section is devoted to present some important research in the field of mining safety risk analysis. Komljenovic et al., (2008)

Corresponding author: Mohammad Javad Rahimdel rahimdel@birjand.ac.ir studied injuries in the mining operations of the US over a 10 -year period from 1995 to 2004 . They categorized injuries into fatalities, non-fatal days-lost, and no-dayslost injuries and then, analyzed the preliminary risk matrix. The results of this study showed a decreasing frequency for all injuries. The fatal and non-fatal days-lost injuries were at a serious level of risk. The no-days-lost injuries were in the moderate level of risk which meant there was no need to consider specific corrective measures, while they needed to be continuously monitored in order to discover any adverse tendency. Kumar and Ghosh (2014) analyzed large mining machinery-related accidents in the opencast coal mines of India from 1995 to 2008. They stated that human and operator faults were the main reason for a large number of fatal accidents. Dump trucks caused $59 \%$ of the fatal accidents while drilling machines caused only $2 \%$. They also concluded that large machines with state-of-the-art safety systems did not significantly reduce fatal accidents. Shariati (2014) prioritized environmental, health, and safety hazards in the south-west underground mines of Iran using the fuzzy risk priority number approach. The results of this study showed that roof collapse, water pollution, dust, accident, rockburst, lack of fresh air, gas, air pollution, noise, and subsidence, respectively are the most hazardous factors in the studied mine. In another study, Sanmiquel et al., (2015) studied accidents in Spain's mines from 2003 to 2012. They stated that collisions with a moving object and physical effort or radiations were the main causes of accidents. Wang et al., (2016) 
Table 1: Research in the field of safety risk analysis in mining

\begin{tabular}{|l|l|}
\hline Subject of study & Researcher(s) \\
\hline Injury analysis in US mines & Komljenovic et al., 2008 \\
\hline Analysis of work-related accidents in Spanish mines & Sanmiquel et al., 2010 \\
\hline The accident analysis of mobile mine machinery in Indian opencast coal mines & Kumar and Ghosh, 2014 \\
\hline Health, safety and environmental risk assessment of underground mines in Iran & Shariati, 2014 \\
\hline Haul truck-related fatal accidents in surface mining & Zhang et al., 2014 \\
\hline Incidence and accident analysis in Spanish stone mines & Sanmiquel et al., 2014 \\
\hline Accident analysis in Spanish mines & Sanmiquel et al., 2015 \\
\hline Safety evaluation of coal mines & Wang et al., 2016 \\
\hline Occupational health hazards analysis of an Indian underground coal mine & Samantra et al., 2017 \\
\hline Safety analysis of workers in Indian mines & Verma and Chaudhari 2017 \\
\hline Safety hazards in Indian underground coal mines & Tripathy et al., 2018 \\
\hline Evaluation of risks in underground mining & Domínguez et al., 2019 \\
\hline Injury analysis in the mining industry of Ghana & Stemn, 2019 \\
\hline
\end{tabular}

applied the fuzzy Analysis Hierarchy Process method to prioritize the risk factors in the underground coal mines of China. They concluded that temperature, safety training, work intensity, and humidity had the greatest effect on the safety risk level while, dust-proof, fire-fighting, and drainage equipment had less of an impact. Stemn (2019) studied occupational accidents of the mining industry over a 10-year period in Ghana. Regarding this study, $85 \%$ of all injuries and $90 \%$ of all fatalities were related to mining equipment. It was also found that the less-experienced workers were involved in fatal accidents more than nonfatal accidents. Moreover, the maintenance, operating mobile equipment, and clean up/ clearing were reported as the most dangerous activities. Ivaz et al., (2020) analyzed fatal injuries in the underground coal mines of Serbia. The results of this study indicate that changes in health and safety legislation significantly decrease fatal injuries. Fatal injuries were higher in groups of older workers and in excavation jobs that demand workers of lower education.

A review of the papers mentioned above shows that many researchers have studied work-related accidents in mining activities. Most of these studies have mainly focused on analyzing accidents without considering the type of mining operation. The ore deposit type and, accordingly, its exploitation method are important factors that affect the frequency and magnitude of the adverse outcomes of incidents. For example, using a diamond wire cutting machine for extracting decorative stones in quarry mines might cause different levels of injury frequency and magnitude in comparison to the mines being exploited by other methods, such as drilling and blasting. Moreover, incidents of potential diseases do not have the same effect on human health and safety. Therefore, to consider adequate health and safety guidelines, different mining activities need to be prioritized based on their fatal or non-fatal injury risk. To overcome these scarcities, in this paper, Iran's mining activities are categorized into four main mineral types including coal, iron ore, metalliferous (including lead and zinc, gold, copper, chromite, manganite, and bauxite) and quarry (including decorative stone, sand, Caracas stone, ballast, limestone, kaolin and fireclay, dolomite and chalk) and then, the likelihood and magnitude of the accident-related injuries including PD, TTD, TPD, and even fatality are calculated and analyzed. The systematic injury risk analysis is done using real data from 2012 to 2015 and the importance measure of each injury is identified using the Analytic Hierarchy Process (AHP) method. To prioritize different mineral types, the overall injury risk is calculated by implementing the degree of importance of injuries and systematic injury risk.

The results of this study identify hazardous incidents in different mining activities. Moreover, the mineral types are prioritized based on the overall injury risk levels to consider the health and safety guidelines.

The rest of this paper is organized as follows. In section 2, the AHP and systematic risk assessment methods are presented. The work-related accidents in Iran's mines are introduced and analyzed in section 3. Finally, in section 4 , the injury risk of mining activities is calculated and mineral types are prioritized based on the overall injury risk.

\section{Theatrical Foundation}

In this section, first, the Analytic Hierarchy Process (AHP) method is presented, and then, the injury risk assessment by integrating the AHP, and the systematic risk approaches are introduced.

\subsection{AHP Method}

AHP is based on the intrinsic human ability to make judgments about small problems presented by Saaty (1980). The AHP method has normally been implemented in conjunction with using the expert choice and applied in a variety of decisions and planning projects. In 
the last few decades, AHP has been successfully applied to practical mining problems, such as mining truck selection (Komljenović and Kecojević 2011), the assessment of coal mining environment security (Juan and Long 2011), coal mine safety assessment (Donget et al., 2013), mining method selection (Yavuz 2015), fan selection for underground coal mine (Kursunoglu and Onder 2015), mine road safety evaluation (Qin and Zhang 2016), the selection of a mineral processing plant site (Bakhtavar and Lotfian 2017), crusher selection (Rahimdel and Ataei 2017), risk assessment of manganese mines (Verma and Chaudhari 2017), human factor analysis of coal mine accidents (Liu et al., 2018) and solutions for the vibrational health risk reduction of mining trucks (Rahimdel and Mirzaei 2020).

The steps of the AHP method are briefly given as follows (Rahimdel and Ataei 2017):

\section{Step 1. Constructing the judgment matrix}

In the first step of AHP, the judgment matrix is expressed mathematically by using simple pairwise comparison as Equation 1:

$$
A=\left(a_{i j}\right)_{n \times n}=\left[\begin{array}{cccc}
1 & a_{12} & \ldots & a_{1 n} \\
a_{21} & 1 & \ldots & a_{2 n} \\
\vdots & \vdots & 1 & \vdots \\
1 / a_{1 n} & 1 / a_{2 n} & \ldots & 1
\end{array}\right], i, j=1,2, \ldots, n
$$

Where:

$A$ - the judgment matrix that compares element $i$ with element $j$ in which $a_{i j}=1 / a_{i j}$.

$a_{i j}$ - the numerical quantities representing the verbal judgments

$n$ - the number of criteria

AHP uses simple pairwise comparisons to determine weights and therefore, the verbal judgments are translated into a score. In this study, the numerical scales used in corresponding to each linguistic variable are given in Table 2.

Table 2: Linguistic variables and their corresponding numerical scales

\begin{tabular}{|l|c|}
\hline Linguistic scale for importance & Numerical scales \\
\hline Just equal & 0.1 \\
\hline Equal importance & 0.3 \\
\hline Weak importance of one over another & 0.5 \\
\hline Moderately importance & 0.7 \\
\hline Essential or strong importance & 0.9 \\
\hline Very strong importance & 1 \\
\hline
\end{tabular}

\section{Step 2. Calculating the weight vector of the judgment matrix}

In this step, a technique the like normalized geometric mean method is used to calculate the relative weights of the judgment matrix elements as Equation 2:

$$
w_{i}=\left(\Pi_{j=1}^{n} a_{i j}\right)^{1 / n} / \Sigma_{i=1}^{n}\left(\prod_{j=1}^{n} a_{i j}\right)^{1 / n} i, j=1,2, \ldots, n
$$

Where:

$w_{i}$ - the weight of the $i$ th criteria

$a_{i j}-$ the numerical quantities representing the verbal judgments

$n$ - the number of criteria

\section{Step 3. Calculating the consistency rate}

To assure a certain quality level of the decision, the consistency of evaluation is analyzed. In order to test the consistency value of the comparison matrix, the consistency rate has to be computed as Equation 3:

$$
C R=\frac{C I}{R I}
$$

Where:

$C I$ - the consistency index

$R I$ - the random index

The consistency index of the comparison matrix is calculated as Equation 4:

$$
C I=\left(\lambda_{\max }-n\right) /(n-1),
$$

Where:

CI - the consistency index

$n$ - the size of the matrix

$\lambda_{\max }$ - the maximum eigenvalue of the decision matrix that is calculated as Equation 5:

$$
A \times W=\lambda . W
$$

Where:

$W$ - the weight vector

$\lambda$ - the eigenvalue of the matrix $A$

The random index is also calculated as Equation 6:

$$
R I=1.98 \times(n-2) / n
$$

Where:

$n$ - the number of criteria

$R I$ - the random index

According to Saaty (1980), in the AHP model, a comparison matrix with $C I$ lower than or equal to 0.10 is sufficiently inconsistent. For inconsistent judgments, the computed values for the pairwise comparison matrixes are between zero and one, which depends on the degree of inconsistency and the values of the tolerance parameters.

\subsection{Systematic risk assessment}

Risk is defined as the uncertainty and lack of awareness about the consequences which can lead to a loss or benefit of action or incident. Risk assessment is a systematic analysis for identifying or quantifying the frequencies and magnitude of the adverse consequences of 
an incident. These parameters are involved in the risk management and the incident's risk $\left(R_{i}\right)$ could be calculated by using a simple mathematical representation, as seen in Equation 7 (Modarres 2006):

$$
R_{i}=P_{i} \cdot C_{i}
$$

Where:

$P_{i}$ - the frequencies or probability of incident

$C_{i}$ - the amount of adverse consequence caused by incident or the magnitude of potential losses

In general, the overall amount of incident's risk $\left(R_{x}\right)$ for $n$ number of incidents can be represented by Equation 8:

$$
R_{x}=\sum_{i=1}^{n} P_{i} \cdot C_{i}
$$

Where:

$P_{i}$ - the probability of the $i$ th incident

$C_{i}$ - the magnitude of potential losses for the $i$ th incident

$n$ - the number of incidents

As all incidents do not have the same degree of importance, it is essential to consider the incidents' importance measure. Therefore, with considering the degree of importance of the incident, the weighted incident risk is calculated with Equation 9:

$$
R_{w}=\sum_{i=1}^{n} w_{i} \cdot R_{i}
$$

Where:

$R_{w}$ - the weighted incident risk

$w_{i}$ - the degree of importance of the $i$ th incident

$R_{i}$ - the risk of the $i$ th incident

$n$ - the number of incidents

In this way, the final weighted risk is sorted to give a prioritized list of mines.

\section{Analyzing occupational accidents in Iran's mines}

Iran is one of the main mineral producers in the world and mining is an important economic sector of this country. Iran ranks among one of the 15 major mineral-rich countries in the world. It has 68 types of minerals with 37 billion tons of proven reserves and more than 57 billion tons of potential reserves. The population of Iran is about 80 million, which is one percent of the world's population, while there is more than seven percent of the total world mineral reserves in this country (NCSI 2019). Regarding the National Statistical Centre of Iran (NSCI), there are about 5000 active mines in Iran with 12 metal and 36 non-metal ores currently being exploited, which can be categorized as coal, iron ore, metalliferous, and quarry. Some useful information about Iran's mines in 2016 and 2017 are summarized in Table 3.

Occupational health and safety is an important issue in mining operations. Hazards encountered in each min-
Table 3: Number of mines, employees and minerals production in 2016 and 2017 (NSCI 2019)

\begin{tabular}{|l|c|c|c|c|}
\hline $\begin{array}{l}\text { Mineral } \\
\text { type }\end{array}$ & Year & $\begin{array}{c}\text { Number } \\
\text { of mines } \\
\text { in operation }\end{array}$ & $\begin{array}{c}\text { Number of } \\
\text { employes }\end{array}$ & $\begin{array}{c}\text { Production } \\
\text { (ton) }\end{array}$ \\
\hline \multirow{2}{*}{ Coal } & 2016 & 92 & 10136 & 3250821 \\
\cline { 2 - 5 } & 2017 & 88 & 9997 & 3436958 \\
\hline \multirow{2}{*}{ Iron ore } & 2016 & 119 & 25042 & 57328697 \\
\cline { 2 - 5 } & 2017 & 135 & 25688 & 68440187 \\
\hline \multirow{2}{*}{$\begin{array}{l}\text { Metalli- } \\
\text { ferous }\end{array}$} & 2016 & 155 & 15500 & 12450705 \\
\cline { 2 - 5 } Quarry & 2017 & 211 & 16412 & 13087059 \\
\cline { 2 - 5 } & 2016 & 4047 & 38260 & 269830083 \\
\hline \multirow{2}{*}{2017} & 4398 & 39353 & 265258022 \\
\hline
\end{tabular}

ing activity need to be recognized to prioritize the dangerous areas in which the safety system is weak. Studying and analyzing the occurred incidents is a helpful method to improve this factor. Therefore, in the rest of this section, the injury-related accidents in different types of Iran's mines are analyzed. To achieve this, the analyses are performed for coal, iron ore, metalliferous and quarry mines from 2012 to 2017. Figure 1 shows the incident frequency per the number of mineral types. According to Figure 1, the coal mines, with 6.56 incidents per mine on average, has the highest incident frequency. In 2014 and 2015, the number of incidents in coal mines has been approximately constant while it increased by 70.22 percent from 2015 to 2016 and 60.49 percent from 2015 to 2017. The frequency of incidents has increased in the iron ore and metalliferous mines by only 22.89 and 15 percent, respectively. It should be noted that the average incident frequency in iron ore, metalliferous, and quarry mines are $1.21,1.16$, and 0.14 respectively, which shows that the lowest number of incidents occur in quarry mines.

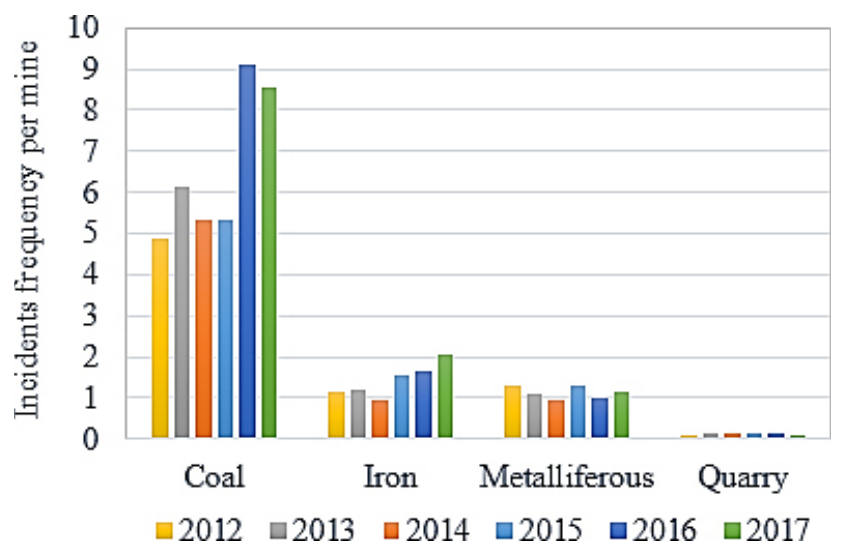

Figure 1: The frequency of incidents for Iran's mineral types from 2012 to 2017

Since the number of the mine's employees exposed to the adverse consequences of incidents is not the same, the frequency of incidents per 1000 employees has been calculated and given in Table 4. According to Table 4, 
the coal and quarry mines, respectively have the highest and lowest frequency of incidents. The frequency of incidents per 1000 coal mine employees decreased significantly after 2013 while it sharply increased in 2016 and 2017. The incident frequency of iron ore and metalliferous mineral types has increased from 2016 to 2017. The results indicate that coal mines are the most incidentprone mines of Iran.

Table 4: The incident frequency per 1000 employees

\begin{tabular}{|l|c|c|c|c|c|c|}
\hline $\begin{array}{l}\text { Mineral } \\
\text { type }\end{array}$ & $\mathbf{2 0 1 2}$ & $\mathbf{2 0 1 3}$ & $\mathbf{2 0 1 4}$ & $\mathbf{2 0 1 5}$ & $\mathbf{2 0 1 6}$ & $\mathbf{2 0 1 7}$ \\
\hline Coal & 55.27 & 68.79 & 59.32 & 56.00 & 116.60 & 92.65 \\
\hline Iron ore & 32.20 & 31.53 & 24.10 & 39.17 & 30.27 & 42.84 \\
\hline Metalliferous & 27.01 & 25.02 & 21.17 & 25.14 & 23.36 & 33.48 \\
\hline Quarry & 13.38 & 19.22 & 22.73 & 20.24 & 24.52 & 16.88 \\
\hline
\end{tabular}

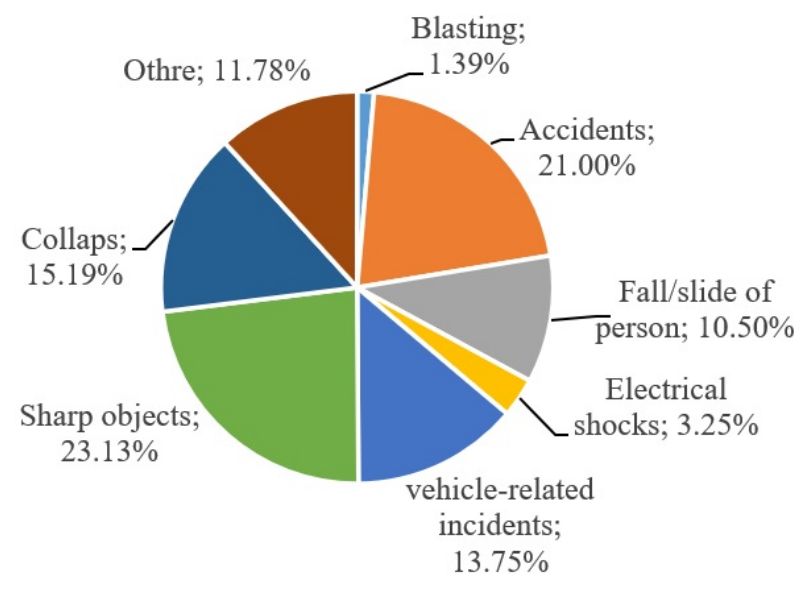

Figure 2: Distribution of incidents' causes in 2017
Regarding NSCI, the distribution of accident-related injuries for Iran's mines in 2017 is calculated and shown in Figure 2. According to Figure 2, sharp objects, traffic-related accidents, and collapse with 23.13, 21, and 15.19 percent of all incidents, respectively, were the main causes of incidents. The main incident types for different mines are also given in Table 5. Regarding Table 5, collapse and sharp objects were the most frequent accidents of the coal and quarry mines, while traffic-related accidents were the main reason for incidents in metalliferous and iron ore mines.

\section{Injury risk analysis for Iran's Mines}

This section is devoted to assessing the injury risk and then ranking Iran's mining activities. In the first step, all injuries should be recognized as adverse consequences. The distribution of injuries based on the human body part is calculated regarding the reports of NSCI in 2017 and shown in Figure 3. According to Figure 3, the upper and lower body were the injured body parts with the highest and lowest injured frequency, respectively. Three parts of the body, including the upper body, lower body, and head were involved in $71.52 \%$ of all injured parts. It is noted that the upper body-related injuries in coal, iron ore, metalliferous, and quarry mines were contained $30.80,29.48,38.83$, and 44.59 percent of all injuries, respectively.

All injuries caused by incidents lead to adverse losses, including the PD, TTD, TPD, and even fatality. Figure 4 shows the adverse consequences per year for each type of Iran's mines. According to Figure 4, most employees in the coal and quarry mines suffered from inci-

Table 5: The number and causes of accident in 2017

\begin{tabular}{|l|c|c|c|c|c|c|c|c|}
\hline Mineral type & Blasting & Accident & $\begin{array}{c}\text { Fall/slide of } \\
\text { person }\end{array}$ & $\begin{array}{c}\text { Electrical } \\
\text { shocks }\end{array}$ & $\begin{array}{c}\text { vehicle-related } \\
\text { incidents }\end{array}$ & $\begin{array}{c}\text { Sharp } \\
\text { objectives }\end{array}$ & Collapse & Other \\
\hline Coal & 6 & 188 & 33 & 1 & 39 & 129 & 221 & 137 \\
\hline Iron ore & 2 & 65 & 66 & 16 & 36 & 46 & 5 & 37 \\
\hline Metalliferous & 8 & 49 & 42 & 9 & 37 & 54 & 22 & 20 \\
\hline Quarry & 10 & 84 & 55 & 35 & 135 & 192 & 13 & 18 \\
\hline
\end{tabular}

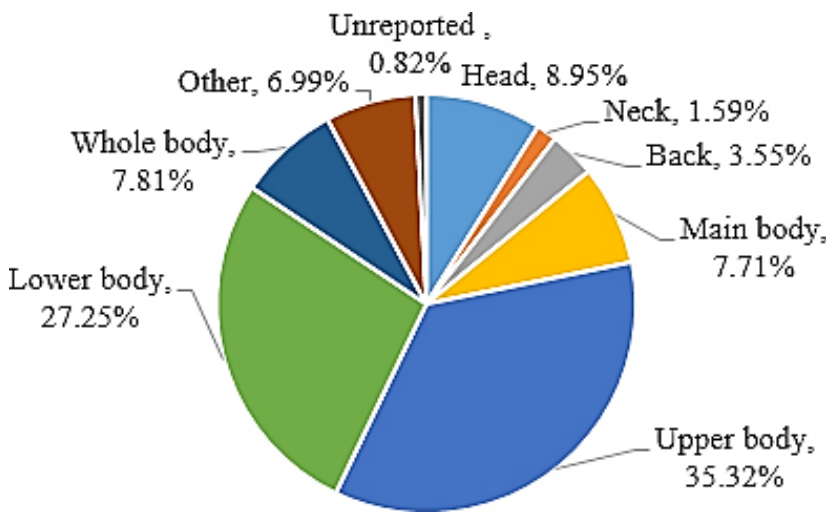

Figure 3: Distribution of injuries based on body part in 2017 dents that cause PD. The TTD had the lowest probability at all mines and was zero in most cases. The TPD probability in the coal, iron ore, metalliferous and quarry mines respectively, was $0.0059,0.0161,0.0626$, and 0.0253 , on average. In other words, the metalliferous and quarry mines had the highest TPD probability, respectively. The probability of fatality in coal mines had a downward trend from 2012 to 2016 , but it increased about 16 times in 2017. It is worth mentioning that this refers to a disaster event accrued in Zemestan-Yurt underground coal mine in the Golestan Province of Iran. On May 3, 2017, when miners were trying to power a locomotive using an external battery, a gas explosion oc- 

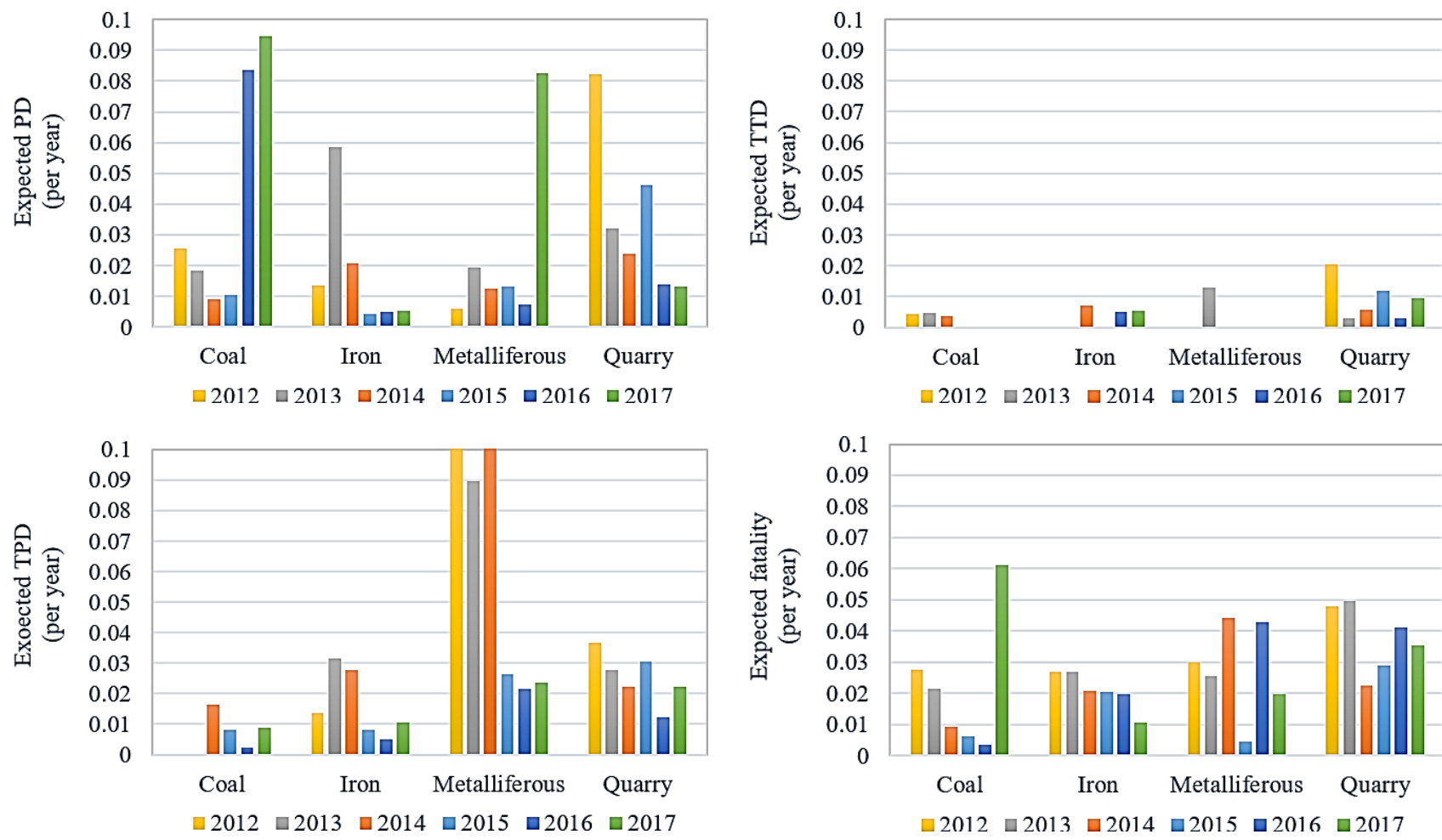

Figure 4: Consequence per year in the various mineral types of Iran

curred and 42 workers were killed and at least 75 workers were injured. On the whole, the probability of fatality was higher in quarry mines in comparison to other mines for the reviewed period. It is worth noting that the probability of fatality in iron mines has significantly decreased over the passing years.

In the following section, the injury risk of each mine is evaluated and then the weighted injury risk is calculated by considering the degree of importance of incidents. To achieve this, at first, the expected injuries from each incident and the number of people sharing the risk were considered for each mineral type, and then, the injury risk of each adverse consequence for different mineral types was calculated. For example, regarding Figure 4, the expected partial disability per year in the coal mine is 0.095 in 2017. Considering the total of 8138 persons exposed to risk, then the partial disability risk is calculated as $1.165 \mathrm{e}-5(=0.095 / 8138)$ per employee per year. The results are given in Figure 5. According to Figure 5, the TTD risk was at the lowest level of all mining activities. In coal mines, the TTD and TPD risks were at the lowest level while, the PD and fatality risk increased sharply in recent years, respectively. That is due to numerous accidents which occurred in underground coal mines, where gas explosions were the main incidents. In iron mining, fatality was the main consequence of incidents and all types of injury risks had a downward trend in recent years. In metalliferous mines, all risk values were so varied over the passing years. For example, the fatality risk had a downward trend in 2013 , 2015, and 2017, but it had an upward trend in 2014 and
2016. It is noted that from 2016 to 2017, the PD risk increased 17 times, while the fatality risk decreased by about 30 percent. These changes persuade us to consider the degree of importance of each adverse consequence to find the most hazardous working places. In quarry mining, all risks were at the lowest levels in comparison to other mining activities. It should be noted that the fatality risk of quarry mines was higher than other risks in recent years.

The rest of this section is devoted to ranking mining activities based on the risk of injury. To reach this, the weight of each consequence was identified using the AHP method and then, the weighted injury risk was calculated for different types of mines. In this study, technical experts in the field of health and safety were used. Some questionnaires about the degree of importance of each adverse consequences (injuries) were prepared and filled out by mine safety and health experts. The experts were asked to state their judgments about the degree of importance of the incidents using linguistic scales. Then, numerical scales, as shown in Table 2, were used to quantify the linguistic scales. In the first step of the AHP, the quantitative data, obtained from the questionnaires, was averaged and the comparison judgment matrix was created as Table 6.

After creating the judgment matrix, the weight vector of the matrix was calculated using the normalized geometric mean method using Equation 2. For example, considering four adverse consequences $(n=4)$, the degree of importance of consequence PD $\left(w_{P D}\right)$ are calculated using Equation 2 and Table 6 as: 

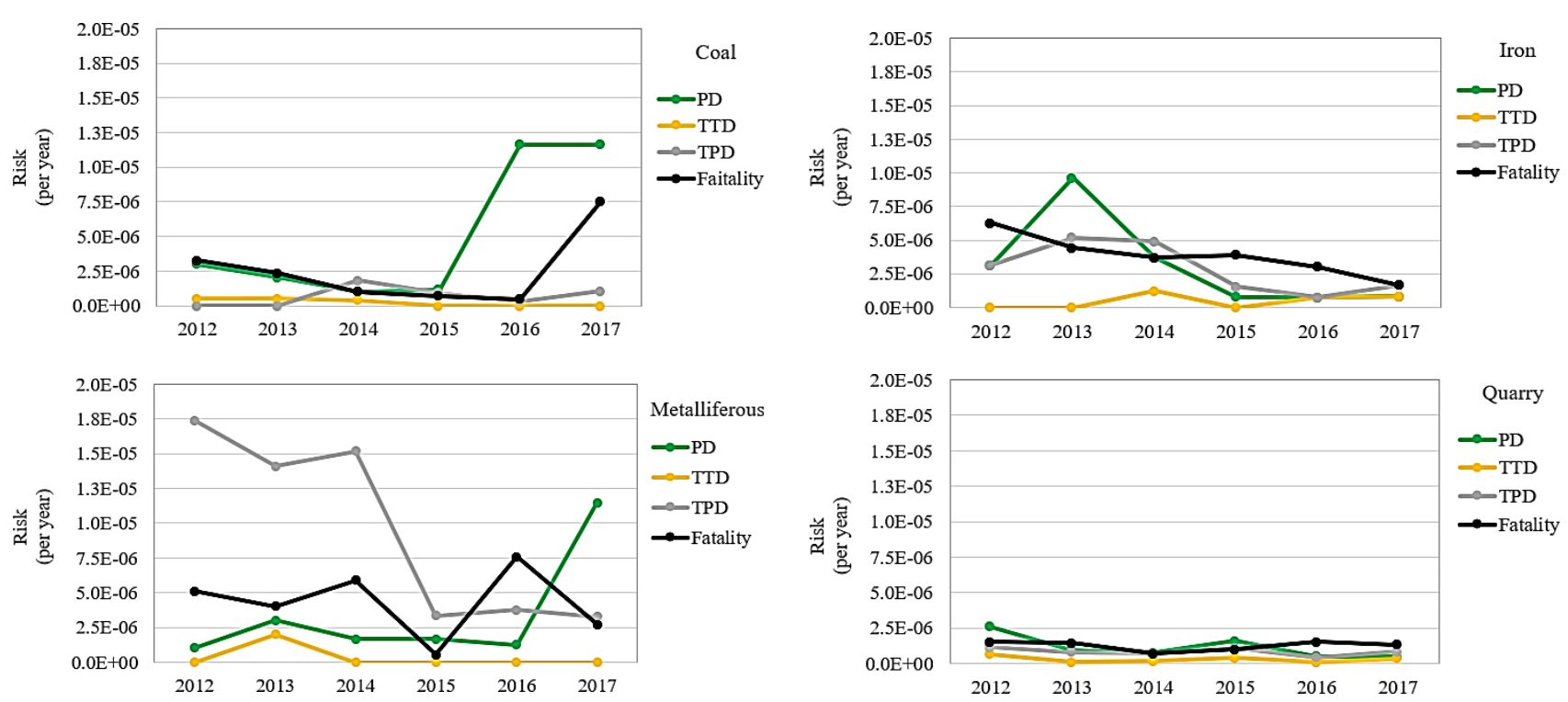

Figure 5: Annual injury risk for different mining activities from 2012 to 2017

$w_{P D}=\frac{\left(\prod_{j=1}^{4} a_{i j}\right)^{\frac{1}{4}}}{\sum_{i=1}^{4}\left(\prod_{j=1}^{4} a_{i j}\right)^{\frac{1}{4}}}=\frac{(1 \times 0.467 \times 0.433 \times 0.067)^{\frac{1}{4}}}{(1 \times 0.467 \times 0.433 \times 0.067)^{\frac{1}{4}}+(2.143 \times 1 \times 0.500 \times 0.150)^{\frac{1}{4}}+(2.308 \times 2.000 \times 1 \times 0.633)^{\frac{1}{4}}+(15.000 \times 6.667 \times 1.579 \times 1)^{\frac{1}{4}}}=0.058$

Table 6: The judgment matrix of the adverse consequence

\begin{tabular}{|l|c|c|c|c|}
\hline & PD & TTD & TPD & Fatality \\
\hline PD & 1 & 0.467 & 0.433 & 0.067 \\
\hline TTD & 2.143 & 1 & 0.500 & 0.150 \\
\hline TPD & 2.308 & 2.000 & 1 & 0.633 \\
\hline Fatality & 15.000 & 6.667 & 1.579 & 1 \\
\hline
\end{tabular}

The results show that the normalized degree of importance of adverse consequences of incidents, including PD, TTD, TPD and fatality was $0.058,0.109,0.224$, and 0.608 , respectively. Considering the judgment matrix, $A$ (see Table 6) and the weight vector for all incidents $(W)$, the eigenvalue of the judgment matrix $(\lambda)$ is calculated using Equation 5 as follows:

$$
A \times W=\lambda . W=\left[\begin{array}{cccc}
1 & 0.467 & 0.433 & 0.067 \\
2.143 & 1 & 0.500 & 0.150 \\
2.308 & 2.000 & 1 & 0.633 \\
15.000 & 6.667 & 1.579 & 1
\end{array}\right]\left[\begin{array}{l}
0.058 \\
0.109 \\
0.227 \\
0.608
\end{array}\right]=\lambda \cdot\left[\begin{array}{l}
0.058 \\
0.109 \\
0.227 \\
0.608
\end{array}\right]
$$

Then,

$$
\lambda=\left[\begin{array}{l}
4.223 \\
4.026 \\
4.287 \\
4.215
\end{array}\right]
$$

The maximum eigenvalue of the judgment matrix $\left(\lambda_{\max }\right)$ or the average over the elements in the resulting vector was calculated 4.188. The dimension of the matrix was 4 and therefore the random index was calculated $(R I=1.980 \times[(n-2) / n]=) 0.990$ using Equation 6. According to Equation 4, the consistency index was also $\left(C I=\left(\lambda_{\max }-n\right) /(n-1)=(4.188-4) /(4-1)=\right) 0.063$. Therefore, the consistency ratio was calculated $(C R=C I /$ $R I=(0.063 / 0.990)=) 0.064$ which is lower than 0.1 . On the other hand, the consistency of the judgment in the comparison matrix was acceptable.

Considering the weight of adverse consequences, the weighted injury risk $\left(R_{w}\right)$ for all mineral types was obtained using Equation 9. For example, the overall risk for coal mines is $5.4 \mathrm{e}-6(=(116.4 \mathrm{e}-7 \times 0.058)+(10$.

\begin{tabular}{|c|c|c|c|c|c|c|c|c|c|c|}
\hline \multirow{2}{*}{ Mineral type } & \multicolumn{2}{|c|}{ PD } & \multicolumn{2}{|c|}{ TTD } & \multicolumn{2}{|c|}{ TPD } & \multicolumn{2}{|c|}{ Fatality } & \multirow{2}{*}{$\boldsymbol{R}_{w}$} & \multirow{2}{*}{ Rank } \\
\hline & IR* & ID** & IR* & ID** & IR* & ID** & IR* & ID $* *$ & & \\
\hline Coal & $116.4 \mathrm{e}-7$ & 0.058 & $10.7 \mathrm{e}-7$ & 0.109 & 0 & 0.224 & $75.1 \mathrm{e}-7$ & 0.608 & $5.4 \mathrm{e}-6$ & 1 \\
\hline Iron ore & $8.3 \mathrm{e}-7$ & 0.058 & $16.6 \mathrm{e}-7$ & 0.109 & $8.3 \mathrm{e}-7$ & 0.224 & $16.6 \mathrm{e}-7$ & 0.608 & $1.4 \mathrm{e}-6$ & 3 \\
\hline Metalliferous & $114.9 \mathrm{e}-7$ & 0.058 & $32.8 \mathrm{e}-7$ & 0.109 & 0 & 0.224 & $27.3 e-7$ & 0.608 & $2.7 \mathrm{e}-6$ & 2 \\
\hline Quarry & $4.9 \mathrm{e}-7$ & 0.058 & $8.4 \mathrm{e}-7$ & 0.109 & $3.5 \mathrm{e}-7$ & 0.224 & $13.2 \mathrm{e}-7$ & 0.608 & $1.0 \mathrm{e}-6$ & 4 \\
\hline
\end{tabular}

Table 7: Priority of the mineral types based on the weighted injury risk

*Injury risk (per person per year), **Importance degree 
$7 \mathrm{e}-7 \times 0.109)+(0 \times 0.224)+(75.1 \mathrm{e}-7 \times 0.608))$ per person. The results are given in Table 7. The priority of each mining activity based on the weighted injury risk is also given in Table 7.

According to Table 7, the extraction of coal with an overall injury risk of 5.4 per one million persons is the most dangerous mining activity in Iran. There are more than 90 coal mines in Iran with more than 144 million tons proven reserves and more than three million tons of annual production. All coal mines are exploited with the underground method and about 10,000 workers are exposed to the health and safety hazards at workplaces. The collapse of roof and blasting are the most common causes of incidents in Iran's coal mining and the risk adjustment strategies such as improving the roof condition and its stability, supervising and checking all safety considerations, and also using a proper educational system should be considered for reducing risk levels.

\section{Conclusions}

This paper studied the occupational accidents that occur during various mining operations in Iran to prioritize different mineral extraction sectors based on injury risk. To achieve this, the adverse consequences of work-related accidents, including partial disability, total temporary disability, total permanent disability, and fatality were studied and analyzed for coal, iron ore, metalliferous, and quarry mineral types of Iran. By considering the importance weight of each consequence, obtained from the analytical hierarchy process, the weighted injury risk was calculated and mining activities were prioritized based on the overall injury risk. The results of this study show that collapse and sharp objects, traffic-related accidents, and vehicle-related incidents were the main causes of incidents in Iran's mines. The upper body, lower body, and head are involved as the most frequently injured parts of the human body. Risk analysis shows that coal mines have the highest level of fatality risks, in comparison to the other mineral types. The overall injury risk analysis indicates that coal, metalliferous, iron ore, and quarry mines, respectively were the most dangerous mining workplaces in Iran. The results of this study can overcome some shortcomings of the conventional statistical risk assessment. They are helpful for mine managers and directors to create a safe working place for their employees and protect them from occupational incidents. They can also be useful to establish policies for the minimization of the occupational hazard rate in the mining workplace.

\section{References}

Bakhtavar, E, Lotfian, R. (2017): Applying an integrated fuzzy gray MCDM approach: A case study on mineral processing plant site selection. Int. Journal of Mining \& Geo-Engineering, 51, 2, 177-183.
Domínguez, C.R., Martínez, I.V., Peña, P.M.P. and Ochoa, A.R., (2019): Analysis and evaluation of risks in underground mining using the decision matrix risk-assessment (DMRA) technique, in Guanajuato, Mexico. Journal of Sustainable Mining, 18, 1, 52-59.

Dong, S.H, Zhao, Y.K, Li, M. (2013): Improvement of Analytic Hierarchy Process and Its Application for Coal Mine Safety Assessment. In Applied Mechanics and Materials. Trans Tech Publications, 368, 1979-1984.

Hossaini, M, Behraftar, S. (2009): Geotechnical risk assessment in Kerman coal mine-central Iran. Research Online, 319.

Ivaz, J, Stojadinović, S, Petrović, D, Stojković, P. (2020): Analysis of fatal injuries in Serbian underground coal mines-50 years review. International journal of injury control and safety promotion, 27, 3, 362-377.

Juan, L, Long, J. (2011): Coal mining environment security assessment based on AHP-Taking Luolong coal mine in Guizhou province for example. In Remote Sensing, Environment and Transportation Engineering (RSETE), 2011 International Conference, 8112-8114.

Komljenovic, D, Groves, W.A, Kecojevic, V.J. (2008): Injuries in US mining operations-A preliminary risk analysis. Safety Science, 46, 5, 792-801.

Komljenović, D, Kecojević, V. (2011): An approach regarding selection of mining trucks. Rudarski radovi, Bor, 2, 89-112.

Kumar, R, Ghosh, A.K. (2014): The accident analysis of mobile mine machinery in Indian opencast coal mines. International journal of injury control and safety promotion, 21 , 1, 54-60.

Kursunoglu, N, Onder, M. (2015): Selection of an appropriate fan for an underground coal mine using the Analytic Hierarchy Process. Tunnelling and Underground Space Technology, 48, 101-109.

Liu, R, Cheng, W, Yu, Y, Xu, Q. (2018): Human factors analysis of major coal mine accidents in China based on the HFACS-CM model and AHP method. International Journal of Industrial Ergonomics, 68, 270-279.

Modarres, M. (2006): Risk analysis in engineering: techniques, tools, and trends. CRC press.

National Statistical Centre of Iran, NSCI. (2019): Survey Results of Iran's Active Mines. https://www.amar.org.ir/english.

Qin, C, Zhang, Y. (2016): Evaluation of the safety of mine road based on fuzzy analytic hierarchy process. Journal of transportation technologies, 7, 1, 70.

Rahimdel, M.J, Ataei, M. (2017): Application of analytic hierarchy process to selection of primary crusher. International Journal of Mining Science and Technology, 24, 4, 519-523.

Rahimdel, M.J, Mirzaei, M. (2020): Prioritization of practical solutions for the vibrational health risk reduction of mining trucks using fuzzy decision making. Archives of environmental \& occupational health, 75, 2, 112-126.

Saaty, T. (1980): The Analytic hierarchy presses: planning, priority setting, resource allocation. New York: McGrawHill.

Samantra, C, Datta, S, Mahapatra, S.S. (2017): Analysis of occupational health hazards and associated risks in fuzzy environment: a case research in an Indian underground coal mine. International journal of injury control and safety promotion, 24, 3, 311-327. 
Sanmiquel, L, Freijo, M, Edo, J, Rossell, J.M. (2010): Analysis of work related accidents in the Spanish mining sector from 1982-2006. Journal of safety research, 41, 1, 1-7.

Sanmiquel, L, Rossell, J.M, Vintró, C. (2015): Study of Spanish mining accidents using data mining techniques. Safety science, $75,49-55$.

Sanmiquel, L, Rossell, J.M, Vintró, C, Freijo, M. (2014): Influence of occupational safety management on the incidence rate of occupational accidents in the Spanish industrial and ornamental stone mining. Work, 49, 2, 307-314.

Shariati, S. (2014). Underground mine risk assessment by using FMEA in the presence of uncertainty. Decision Science Letters, 3, 3, 295-304.

Stemn, E. (2019): Analysis of injuries in the Ghanaian mining industry and priority areas for research. Safety and health at work, 10, 2, 151-165.

Tripathy, D.P, Ala, C.K. (2018): Identification of safety hazards in Indian underground coal mines. Journal of Sustainable Mining, 17, 4, 175-183.
Verma, S, Chaudhari, S. (2017): Fuzzy AHP approach for risk assessment in manganese mines of India. International Journal of Decision Sciences, Risk and Management, 7, 3, 169-189.

Verma, S, Chaudhari, S. (2017): Safety of workers in Indian mines: study, analysis, and prediction. Safety and health at work, 8, 3, 267-275.

Wang, Q, Wang, H, Qi, Z. (2016): An application of nonlinear fuzzy analytic hierarchy process in safety evaluation of coal mine. Safety science, 86, 78-87.

Yavuz, M. (2015): The application of the analytic hierarchy process (AHP) and Yager's method in underground mining method selection problem. International Journal of Mining, Reclamation and Environment, 29, 6, 453-475.

Zhang, M, Kecojevic, V, Komljenovic, D. (2014): Investigation of haul truck-related fatal accidents in surface mining using fault tree analysis. Safety science, 65, 106-117.

\section{SAŽETAK}

\section{Analiza ozljeda u iranskim rudnicima}

Rudarstvo i rudarenje visokorizične su aktivnosti koje izlažu radnike i tvrtke velikim opasnostima unutar medicine rada i sigurnosnih rizika. One su uzrokovane nesrećama pri transportu, miniranju ili urušavanju. Ovdje su analizirane ozbiljne ili smrtonosne nesreće u iranskim rudnicima tijekom šestogodišnjega razdoblja, od 2012. do 2017. Izvori su bili statističke analize ozljeda u izvješćima Iranskoga nacionalnoga statističkog centra te podatci prikupljeni tematskim upitnicima od eksperata zaposlenih na rudničkoj sigurnosti i zdravlju. Prikazan je model određivanja prioriteta u rudarenju utemeljen na procjeni opasnosti od ozljeda na radu. Rezultati su pokazali kako iranski rudnici ugljena imaju najveću stopu nesreća te se stoga tamo trebaju razmotriti posebne mjere sigurnosti. Nadalje, najmanji su udjel imale ozljede koje su prouzročile privremenu radnu nesposobnost, dok su one sa smrtonosnim ishodom bile zadnjih godina najzastupljenije. Rezultati će pomoći kod opažanja opasnih radnih uvjeta tijekom rudarenja i tako zaštititi radnike od rizika upućivanjem na sigurnosne mjere.

\section{Ključne riječi:}

rudarski zahvati, rudnici u Iranu, teške ozljede, procjena rizika

\section{Author's contribution}

The author prepared the whole work. 